\title{
Aerobic exercise and not a diet supplemented with jussara açaí (Euterpe edulis Martius) alters hepatic oxidative and inflammatory biomarkers in ApoE-deficient mice
}

Cynthia Aparecida de Castro ${ }^{1 *}$, Antonio José Natali ${ }^{1}$, Luciana Marques Cardoso ${ }^{2}$, Alessandra Barbosa Ferreira-Machado ${ }^{3}$, Alexandre Azevedo Novello ${ }^{4}$, Karina Ana da Silva ${ }^{1}$, Natalia Filard Tafuri ${ }^{4}$, Sergio Luis Pinto da Matta ${ }^{5}$, Maria Lucia Pedrosa ${ }^{6}$ and Maria do Carmo Gouveia Peluzio ${ }^{4}$

${ }^{1}$ Departamento de Educação Física, Universidade Federal de Viçosa (UFV), Avenida Peter Henry Rolfs, s/n, Viçosa, MG 36570000, Brazil

${ }^{2}$ Departamento de Bioquímica e Biologia Molecular, Universidade Federal de Viçosa, Viçosa, MG, Brazil

${ }^{3}$ Departamento de Parasitologia e Microbiologia, Universidade Federal de Juiz de Fora, Juiz de Fora, MG, Brazil

${ }^{4}$ Departamento de Nutrição e Saúde, Universidade Federal de Viçosa, Viçosa, MG, Brazil

${ }^{5}$ Departamento de Biologia Geral, Universidade Federal de Viçosa, Viçosa, MG, Brazil

${ }^{6}$ Departamento de Ciências Biológicas, Universidade Federal de Ouro Preto, Ouro Preto, MG, Brazil

(Submitted 23 July 2013 - Final revision received 26 February 2014 - Accepted 28 February 2014 - First published online 1 May 2014)

\section{Abstract}

The pulp of jussara açaí (Euterpe edulis Martius) fruit is rich in anthocyanins that exert antioxidant and anti-inflammatory effects similar to those exerted by aerobic exercise. In the present study, we investigated the effects of jussara açaí fruit pulp consumption, either alone or in combination with aerobic exercise, on the hepatic oxidative and inflammatory status of ApoE-deficient $\left(A p o E^{-/-}\right)$mice. Male mice were divided into four groups (control (C), control plus açaí, exercise plus açaí (EXA) and exercise (EX)) and fed the AIN-93M diet or the AIN-93M diet formulated to contain $2 \%$ freeze-dried açaí pulp. Mice in the EX and EXA groups were subjected to a progressive running programme $(5 \mathrm{~d} /$ week, $60 \mathrm{~min} / \mathrm{d}, 16 \mathrm{~m} / \mathrm{min})$ for 12 weeks. Mice that were made to exercise exhibited reduced (40.85\%; $P<0 \cdot 05)$ hepatic superoxide dismutase activity when compared with the $\mathrm{C}$ mice, independent of the açaí diet. Mice in the EX group exhibited a lower (42\%; $P<0.05)$ mRNA expression of monocyte chemotactic protein-1 in the liver compared with the $\mathrm{C}$ mice. Mice in the EXA and EX groups had lower percentages of hepatic lipid droplets $(70 \%$ and $56 \%$, respectively; $P<0.05)$ when compared with the C mice. Mice in the EX group had smaller $(58 \% ; P<0.05)$ area of lesions in the aorta when compared with the $\mathrm{C}$ mice. Serum lipid profile was not affected $(P>0 \cdot 05)$. In conclusion, aerobic exercise training rather than açaí fruit pulp consumption or a combination of both enhances the hepatic oxidative and inflammatory status of $A p o E^{-1-}$ mice.

Key words: $\boldsymbol{A p o E}^{-/-}$mice : Atherosclerosis: Anthocyanins: Antioxidants: Physical activity

The pulp of jussara açaí, a fruit of the Euterpe edulis Martius palm tree, contains approximately $6 \%$ protein, $49 \%$ lipids and $43 \%$ carbohydrates and is rich in anthocyanins $(290 \mathrm{mg} / 100 \mathrm{~g}$ wet weight), mainly cyanidin-3-glucoside and cyanidin-3rutinoside ${ }^{(1)}$. Anthocyanins are important plant pigments that belong to a class of phenolic compounds collectively called flavonoids ${ }^{(2)}$. The anthocyanin phenolic structure can confer antioxidant properties through the donation or transfer of electrons from hydrogen atoms. The health-promoting properties of the açaí fruit have become more evident, as epidemiological studies suggest that increased consumption of anthocyanins lowers the risk of CVD, the most common cause of mortality among men and women ${ }^{(3)}$.

Along with the genetic background, risk factors for CVD are associated with lifestyle and eating habits ${ }^{(4,5)}$ and contribute to the pathological frame of atherosclerosis ${ }^{(6)}$. Potentially atherogenic lipoproteins, such as LDL, are associated with both functional and structural changes in the liver ${ }^{(7)}$. These alterations are mainly caused by a combination of excessive production of reactive oxygen species (ROS) and changes in the antioxidant defence system $^{(8)}$. Hepatic inflammation involves several chemokines, including monocyte chemotactic

Abbreviations: C, control; CA, control plus açaí; CAT, catalase; EX, exercise; EXA, exercise plus açaí; MCP, monocyte chemotactic protein; ROS, reactive oxygen species; SOD, superoxide dismutase.

*Corresponding author: C. A. de Castro, fax +553138992249, email cynthiaefi2004@yahoo.com.br 
protein-1 (MCP-1 $)^{(9)}$. The expression of MCP-1 is also thought to play an important role in hepatic steatosis and atherogenesis ${ }^{(10)}$.

In addition to the therapeutic advances made with regard to atherosclerosis, non-pharmacological strategies for its prevention and treatment including eating habits and changes in lifestyle have been investigated. In this regard, the adoption of diets rich in fruits and vegetables and of active lifestyles has been recognised to have beneficial effects ${ }^{(11-13)}$. For instance, the ingestion of the pulp of Amazonian açaí (Euterpe oleracea Martius) has been shown to exert antioxidant and antiinflammatory effects both in human subjects and in animal models $^{(12-14)}$, as well as to exert atheroprotective effects in hyperlipidaemic ApoE-deficient $\left(A p o E^{-/-}\right)$mice fed a highfat diet ${ }^{(13)}$. However, little is known about the atheroprotective effects of the jussara açaí fruit pulp. The recommended active lifestyle of regularly performing moderate-intensity aerobic exercise is thought to reduce oxidative stress in the skeletal muscle and liver and to promote atheroprotective effects and beneficial effects on lipid profile in both humans and animal models, including the $A p O E^{-1-}$ mouse model ${ }^{(15-19)}$

In the present study, we hypothesised that the combination of a diet supplemented with açaí pulp and exercise training may potentiate the effects of jussara açaí pulp consumption on hepatic oxidative and inflammatory biomarkers. Therefore, we investigated the effects of jussara açaí pulp consumption, either alone or in combination with moderate-intensity aerobic exercise training, on the hepatic oxidative and inflammatory status of $A p O E^{-/-}$mice.

\section{Materials and methods}

\section{Animals}

$A p o E^{-/-}$mice (average body weight $25 \mathrm{~g}$ ) aged 21 weeks were obtained from the Central Animal House at the Federal University of Viçosa, Brazil. During the experimental period, the mice were kept in collective cages in a temperature $\left(22 \pm 2^{\circ} \mathrm{C}\right)$ - and humidity (50\%)-controlled room with a $12 \mathrm{~h}$ photoperiod. The national guidelines for the care and use of animals were followed, and all experimental procedures were approved by the institutional ethics committee (Comissão de Ética no Uso de Animais/Federal University of Viçosa) under protocol number 19/2010.

\section{Experimental design}

The mice were divided into four groups as follows: control (C, no exercise training and fed the AIN-93M diet, $n$ 5); control açaí (CA, no exercise training and fed the AIN-93M diet plus açaí, $n$ 6); exercise açaí (EXA, exercise training and fed the AIN-93M diet plus açaí, $n$ 6); exercise (EX, exercise training and fed the AIN-M93 diet, $n$ 6). The mice were treated for twelve consecutive weeks and observed daily, and body weights and food intake were determined weekly.

\section{Experimental diets}

Fresh açaí berries were legally collected in a remaining area of the Atlantic Forest located in the 'Zona da Mata' of Minas
Gerais state, Brazil. After harvesting, the fruits were threshed and transported to the Nutrition and Health Department at the Federal University of Viçosa in airtight plastic bags and were immediately submitted to processing. Fruit pulp was then obtained and lyophilised. The levels of moisture, ash, lipids, proteins and carbohydrates in the freeze-dried pulp were measured. Moisture content was determined by drying the sample in an oven at $105^{\circ} \mathrm{C}$. Total lipid content in a diethyl ether extract was determined by drying the sample at $105^{\circ} \mathrm{C}$ followed by extraction using diethyl ether in a Soxhlet extractor and subsequent removal of the solvent by distillation ${ }^{(20)}$. Protein content was determined using the classic Kjeldahl method, and carbohydrate content was determined by calculating the percentage difference when subtracted from the total sum of moisture, ash, lipid and protein contents. Anthocyanin content was determined using the $\mathrm{pH}$-differential $\operatorname{method}^{(21)}$. The characterisation of the major anthocyanins in the açaí extract was performed using HPLC as described previously ${ }^{(22)}$. Ash content was determined by incineration of the sample in a muffle furnace at $550^{\circ} \mathrm{C}$ and subsequent cooling in a desiccator at room temperature.

The freeze-dried açaí pulp had 8.45\% moisture, 5.28\% protein, $49.35 \%$ lipids and $42.86 \%$ carbohydrates. The total anthocyanin content of the freeze-dried açaí extract was $25.829 \mathrm{mg} / \mathrm{g}$, with $9.524 \mathrm{mg} / \mathrm{g}$ being cyanidin-3-O-glucoside and $16 \cdot 305 \mathrm{mg} / \mathrm{g}$ being cyanidin-3-O-rutinoside.

The diets were prepared according to the Association of Official Analytical Chemists ${ }^{(20)}$ and $\operatorname{AIN} 93 \mathrm{M}^{(23)}$ and were maintained under refrigeration $\left(0-4^{\circ} \mathrm{C}\right)$ and protected from light until use. For the experimental groups to be treated with açaí, $2 \%$ of the lyophilised fruit pulp was added and the diet composition was modified, considering the values of carbohydrates, protein, lipids and dietary fibre (Table 1). The amount of dietary fibre was based on the composition of the E. oleracea Martius fruit ${ }^{(22)}$. The energy contents of the diets were $1590 \mathrm{~kJ} / 100 \mathrm{~g}(380 \mathrm{kcal} / 100 \mathrm{~g}$, AIN-93M) and $1611 \mathrm{~kJ} / 100 \mathrm{~g}$ (385 kcal/100 g, AIN-93M plus açaí). The amount of freeze-dried fruit pulp added to the diets was, on average, $3.25 \mathrm{~g} / \mathrm{kg}$ per $\mathrm{d}$. The $2 \%$ açaí pulp dose was

Table 1. Composition $(\mathrm{g} / \mathrm{kg})$ of the diets fed to $A p o E^{-1-}$ mice

\begin{tabular}{|c|c|c|}
\hline Nutrients & AIN-93M & AIN-93M plus açaí \\
\hline Maize starch* & 51.57 & $52 \cdot 13$ \\
\hline Dextrinised starch* & $15 \cdot 5$ & $15 \cdot 5$ \\
\hline Sucrose* $†$ & $10 \cdot 0$ & $9 \cdot 16$ \\
\hline Casein*† & $9 \cdot 0$ & $8 \cdot 86$ \\
\hline Cellulose* $†$ & $5 \cdot 0$ & $4 \cdot 12$ \\
\hline Mineral mixture* & 3.5 & 3.5 \\
\hline Vitamin mixture* & 1.0 & 1.0 \\
\hline Choline bitartrate $^{\star}$ & 0.25 & 0.25 \\
\hline L-Cys* & 0.18 & 0.18 \\
\hline Açaí pulpł & 0.0 & $2 \cdot 12$ \\
\hline Soyabean oil $^{*} \dagger$ & $4 \cdot 0$ & $3 \cdot 18$ \\
\hline Total & 100 & 100 \\
\hline
\end{tabular}

${ }^{*} \mathrm{AIN}-93 \mathrm{M}$ rodent diet nutrients ${ }^{(23)}$

$\dagger$ The concentration of the nutrient in the fruit was deducted.

†Freeze-dried açaí pulp contains $7 \mathrm{~g}$ protein, $41 \mathrm{~g}$ fat, $42 \mathrm{~g}$ carbohydrates and approximately $44.2 \mathrm{~g}$ dietary fibre $/ 100 \mathrm{~g}$. The total anthocyanin content is $25.829 \mathrm{mg} / \mathrm{g}$ (cyanidin-3-O-glucoside $9.524 \mathrm{mg} / \mathrm{g}$ and cyanidin-3-O-rutinoside $16.305 \mathrm{mg} / \mathrm{g})$. 
chosen because of its relevance to human nutrition. In addition, this dose mimics the addition of a portion of açaí fruit pulp to human food ${ }^{(24)}$ and has been found to have effects in previous studies using rodents ${ }^{(14,25)}$.

\section{Exercise training protocol}

Mice in the EXA and EX groups were subjected to a progressive treadmill (Insight Equipamentos Científicos) running programme, $5 \mathrm{~d}$ per week (Monday to Friday), for twelve consecutive weeks. Briefly, in the first week, the mice were made to run for $30 \mathrm{~min}$ daily at a speed of $12 \mathrm{~m} / \mathrm{min}, 0 \%$ incline. In the second week, the running time and speed were increased to $40 \mathrm{~min} / \mathrm{d}$ and $14 \mathrm{~m} / \mathrm{min}$, respectively. From the third week onwards, the mice were made to run for $60 \mathrm{~min} / \mathrm{d}$ at a speed of $16 \mathrm{~m} / \mathrm{min}$, $0 \%$ incline. Exercise intensity was determined by adjusting the running speed to the oxygen consumption according to the method of Høydal et al. ${ }^{(26)}$.

\section{Sample preparation}

The mice were anaesthetised with ketamine $(10 \mathrm{mg} / \mathrm{kg}$ body weight) and xylazine ( $2 \mathrm{mg} / \mathrm{kg}$ body weight) and killed by increasing the anaesthetic dose followed by puncturing of the abdominal aorta $48 \mathrm{~h}$ after the last exercise session. To determine serum component levels, blood samples were collected in $5 \mathrm{ml}$ test-tubes and centrifuged at $2938 \mathrm{~g}$ at $4^{\circ} \mathrm{C}$ for $10 \mathrm{~min}$. The soleus muscle was harvested, immersed in liquid $\mathrm{N}_{2}$ and stored at $-80^{\circ} \mathrm{C}$ for subsequent analyses. After removal of all the adventitia from the aortic valve to the iliac bifurcation, the aorta was dissected and stored in $10 \%$ formalin for subsequent analyses. The liver was removed, washed in saline and weighed. A fragment of the liver caudate lobe was immersed in Karnovsky solution for $24 \mathrm{~h}$ for histopathological analyses and the remaining fragments were immersed in liquid $\mathrm{N}_{2}$ and stored at $-80^{\circ} \mathrm{C}$ for subsequent analyses.

\section{Measurement of muscle citrate synthase activity}

Citrate synthase activity in the soleus muscle was assessed according to the method of Alp et al. ${ }^{(27)}$. The muscle was weighed and homogenised with a glass homogeniser on ice in a solution of Tris $-\mathrm{HCl}(100 \mathrm{mmol} / \mathrm{l})$ at a constant weight: volume ratio. The homogenate was then added to a reaction mixture containing Tris-HCl $(100 \mathrm{mmol} / \mathrm{l})$, dithiobis(2-nitrobenzoic acid) $(1.0 \mathrm{mmol} / \mathrm{l})$ and acetyl-CoA $(3.9 \mathrm{mmol} / \mathrm{l})$. After the addition of oxaloacetate $(1.0 \mathrm{mmol} / \mathrm{l})$, absorbance was read at $412 \mathrm{~nm}$ for a $7 \mathrm{~min}$ period. Mean absorbance in variation per min was recorded for each sample, and citrate synthase activity was calculated using an extinction coefficient of $13600 \mathrm{~mol} / 1$ per $\mathrm{cm}$.

\section{Liver histopathological analyses}

A fragment of the liver caudate lobe was immersed in Karnovsky solution for $24 \mathrm{~h}$ and was then dehydrated in ethanol and embedded in paraffin. The fragment was cut into $4 \mu \mathrm{m}$ sections, stained with haematoxylin and eosin, and mounted on histology slides with Entellan ${ }^{\circledR}$ (Merck) for the quantification of lipid droplets, inflammatory infiltrates and sinusoidal capillaries. The slides were visualised and the images $(\times 20)$ captured using a light microscope (Olympus BX-60®) connected to a digital camera (Olympus QColor- $3 \AA$ ). A total of ten images from each mouse were used to count lipid droplets (expressed as percentage per histological area). An 810-point grid was imposed on the scanned images via the Image-Pro Plus $4.5 \AA$ software system (Average Cybernetics).

\section{Determination of antioxidant enzyme activity in the liver}

Liver fragments were homogenised in $50 \mathrm{~mm}$-phosphate buffer and the resulting suspension was centrifuged at $3000 \mathrm{~g}$ at $4 \mathrm{C}$ for $10 \mathrm{~min}$. The supernatant was used to measure enzyme activity. Superoxide dismutase (SOD) activity was determined using a microplate reader (Asys UVM 340; Biochrom Ltda), at $570 \mathrm{~nm}$, by evaluating the ability of SOD to remove superoxide $\left(\mathrm{O}_{2}^{-}\right)$anions, thus decreasing the self-oxidation rate of pyrogallol $^{(28)}$. Protein content was measured using the method described by Lowry et al. ${ }^{(29)}$. Catalase (CAT) activity was determined by the rate of decay of $\mathrm{H}_{2} \mathrm{O}_{2}$ read in a spectrophotometer (Pro-analise PAUV.1600; PRO-ANALISE Química e Diagnóstica Ltda) at $240 \mathrm{~nm}$, as described previously ${ }^{(30)}$.

\section{Real-time PCR analysis}

Total mRNA was extracted from a $100 \mathrm{mg}$ liver fragment. The tissue sample was treated with proteinase K (Sigma-Aldrich $®$ ), and the RNA was extracted with TRIzol (Invitrogen), according to the manufacturer's instructions. The purity and quantity of RNA were determined using a spectrophotometer (Thermo Scientific Evolution 60; Thermo Fisher Scientific).

The total RNA ( $2 \mu \mathrm{g}$ ) was used for synthesising complementary DNA using random primers (Promega $\left.{ }^{\circledR}\right)$, buffer, dNTP (Sinapse ${ }^{\circledR}$ ) and Moloney murine leukaemia virus RT (Fermentas ${ }^{\circledR}$ ), according to the manufacturer's instructions. The relative expression of the $M C P-1$ gene was determined by quantitative real-time PCR. The PCR cycle involved an initial denaturation step at $95^{\circ} \mathrm{C}(2 \mathrm{~min})$ followed by forty cycles with $15 \mathrm{~s}$ of denaturation $\left(95^{\circ} \mathrm{C}\right), 30 \mathrm{~s}$ of annealing $\left(60^{\circ} \mathrm{C}\right)$ and $1 \mathrm{~min}$ of extension $\left(72^{\circ} \mathrm{C}\right)$, followed by the standard dissociation curve analysis. Glyceraldehyde 3-phosphate dehydrogenase $(G A P D H)$ gene was used as a control endogenous gene, after finding that its expression was not significantly affected under the experimental conditions. Specific primers used for tissue factor, inducible NO synthase and $\beta$-actin were as follows: for $M C P-1$ - forward $5^{\prime}$-GGTCCCTGTCATGCTTCTGG-3' and reverse $5^{\prime}$-CCTGCTGCTGGTGATCCTCT- $3^{\prime}$; for GAPDH - forward 5'-CCACCCATGGCAAATTCC- $3^{\prime}$ and reverse $5^{\prime}$-GATGGGATTTCCATTGATGACA- $3^{\prime}$. The quantitative analyses were carried out in a thermocycler (Step One Plus; Applied Biosystems Real-Time PCR System) using the fluorescence quantification system (Platinum ${ }^{\circledR}$ SYBR ${ }^{\circledR}$ Green; Invitrogen). All samples were analysed in triplicate. Reaction efficiencies were determined as described previously $^{(31)}$, and amplification specificity was determined by the analysis of the dissociation curves ${ }^{(32)}$. 


\section{Aortic lesion analysis}

Lipid depositions in the aortic arch and in the thoracic aorta were measured using en face analysis with Sudan IV dye ${ }^{(33)}$. The aortas were opened longitudinally and fixed for $12 \mathrm{~h}$ in a formalin-sucrose solution (4\% paraformaldehyde, 5\% sucrose, $20 \mu \mathrm{mol}$ butylated hydroxytoluene/l and $2 \mu \mathrm{mol}$ EDTA/l, pH 7.4) at $4^{\circ} \mathrm{C}$. Later, the aortas were placed in a $70 \%$ ethanol solution for $5 \mathrm{~min}$. Subsequently, the aortas were stained with a solution containing 0.5\% Sudan IV dye, 35\% ethanol and $50 \%$ acetone for $10 \mathrm{~min}$ under agitation and then bleached in an $80 \%$ ethanol solution for $5 \mathrm{~min}$. The stained aortas were photographed using an 8.1 megapixel digital camera with distance, zoom and luminosity being controlled. The analyses were carried out using the Image-Pro Plus ${ }^{\circledR}$ software package. Pixels were converted into $\mathrm{cm}^{2}$ using a standard microscopic scale under the same condition that the aortas were analysed. The sum of the areas of atherosclerotic lesions (where lipid accumulation was observed) was calculated using the software, and the results are expressed in $\mathrm{cm}^{2}$. To ensure that there were no differences in the total size of the aortas among the mice, their area was also measured. The analyses were carried out by two individuals blinded to the study design.

\section{Determination of the serum lipid profile}

The levels of total cholesterol, HDL-cholesterol and TAG were determined by the enzymatic colorimetric method (Cobas ${ }^{\circledR}$, C 111 analyser; Roche) using commercial kits (Bioclin ${ }^{\circledR}$; Quibasa Química Básica Ltda).

\section{Statistical analysis}

All data were submitted to the Kolmogorov-Smirnov test for symmetry and equality of variance. Data obtained for weights and SOD and CAT activities were analysed using the two-way ANOVA followed by Tukey's post hoc test when necessary. Data obtained for $M C P-1$ mRNA expression, lipid profile, area of atherosclerotic lesions and liver histopathology were analysed using the Kruskal-Wallis test followed by Dunn's post hoc test when necessary. Data obtained for muscle citrate synthase activity in mouse groups that were made to and not made to exercise were compared using unpaired Student's $t$ test (SigmaStat version 3.5; Systat). Differences of $P<0.05$ were considered to be statistically significant.

\section{Results}

\section{Body and liver weights and food intake}

There were no significant differences among the experimental groups with regard to their initial body weights and liver weights (Table 2). Mice that were made to exercise had higher final body weights compared with the C mice (26.6 ( $\mathrm{SD} 3.3)$ v. 23.5 (SD 2.7) g, respectively). The average food intake was not different among the groups (data not shown).

\section{Muscle citrate synthase activity}

Citrate synthase activity was measured to assess the impact of the employed aerobic exercise programme on the muscle oxidative capacity. Mice in the EXA ( $1 \cdot 3(\mathrm{SD} 0 \cdot 2) \mathrm{U} / \mathrm{mg}$ protein) and EX (1.3 (SD 0.1) U/mg protein) groups exhibited higher $(P<0.001)$ citrate synthase activity when compared with those in the $\mathrm{C}(0.7(\mathrm{SD} 0.2) \mathrm{U} / \mathrm{mg}$ protein) and $\mathrm{CA}(0.6$ (SD $0 \cdot 2$ ) $\mathrm{U} / \mathrm{mg}$ protein) groups, respectively.

\section{Liver histopathology}

Mice in the $\mathrm{C}$ group exhibited hepatic tissue disorganisation with higher percentages of lipid droplets (Fig. 1(a)) and intense areas of necrosis (mean data not shown). Mice in the EXA and EX groups exhibited lower percentages of lipid droplets when compared with those in the C group (Fig. 1(b)).

Mice in the EX group had a higher number of sinusoidal capillaries in the liver when compared with those in the other groups (Table 3). However, there were no statistically significant differences among the experimental groups regarding the number of hepatocytes and inflammatory infiltrates.

\section{Antioxidant enzyme activity in the liver}

Mice that were made to exercise exhibited a reduced SOD activity when compared with the $\mathrm{C}$ mice (Fig. 2), independent

Table 2. Body weight and liver weight of $A p o E^{-/-}$mice fed a diet supplemented with açaí pulp and made to perform aerobic exercise

(Mean values and standard deviations)

Experimental groups

\begin{tabular}{|c|c|c|c|c|c|c|c|c|}
\hline \multirow[b]{2}{*}{ Measurements ${ }^{*}$} & \multicolumn{2}{|c|}{$C(n 5)$} & \multicolumn{2}{|c|}{$\mathrm{CA}(n 6)$} & \multicolumn{2}{|c|}{$\operatorname{EXA}(n 6)$} & \multicolumn{2}{|c|}{$\mathrm{EX}(n 6)$} \\
\hline & Mean & $\overline{S D}$ & Mean & $\overline{S D}$ & Mean & $\overline{S D}$ & Mean & $\overline{S D}$ \\
\hline Initial body weight† (g) & $24 \cdot 2$ & 2.9 & 23.6 & $2 \cdot 8$ & $23 \cdot 4$ & $3 \cdot 1$ & $25 \cdot 7$ & $3 \cdot 2$ \\
\hline Final body weight $(\mathrm{g})$ & 23.9 & 3.4 & 23.5 & $2 \cdot 1$ & $26 \cdot 1$ & $4 \cdot 0$ & $26 \cdot 6$ & 2.5 \\
\hline Liver weight§ (g) & 1.27 & 0.06 & $1 \cdot 26$ & 0.19 & 1.26 & 0.15 & 1.45 & 0.25 \\
\hline
\end{tabular}

C, control; CA, control plus açaí; EXA, exercise plus açaí; EX, exercise.

* Data were analysed using two-way ANOVA.

†There were no significant main effects for exercise $(P=0.85)$, diet $(P=0.74)$ and interaction $(P=0.66)$.

$\ddagger$ There was a significant main effect for exercise $(P=0.02)$, but no main effects for diet $(P=0.80)$ and interaction $(P=0.71)$.

$\S$ There were no significant main effects for exercise $(P=0.28)$, diet $(P=0.22)$ and interaction $(P=0.29)$. 
(a)

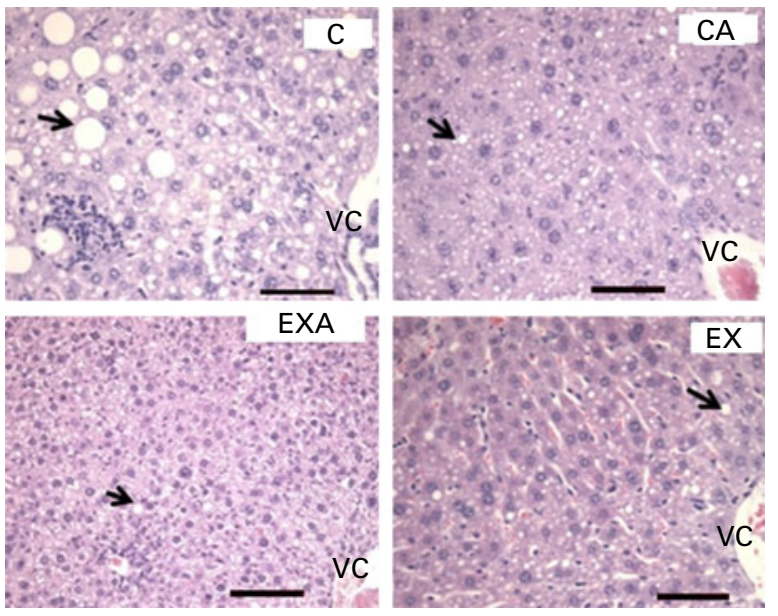

(b)

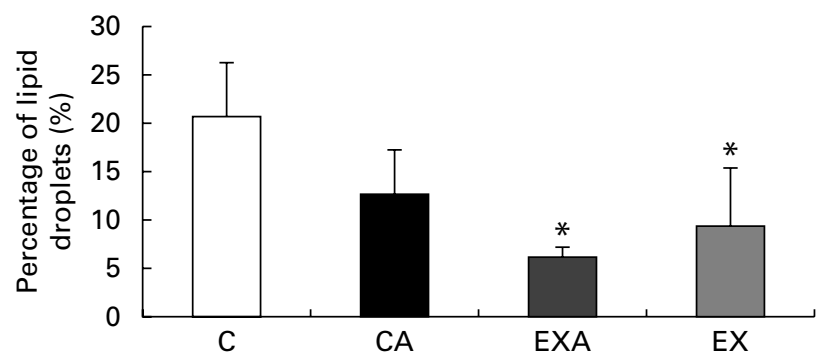

Fig. 1. Effects of açaí diet ingestion and aerobic exercise training on the percentage of lipid droplets in the liver of $A p O E^{-1-}$ mice. (a) Representative photomicrographs of hepatic tissue sections. Arrows indicate lipid droplets. The sections were stained with haematoxylin and eosin. All images were captured at the same magnification. Scale bar represents $65 \mu \mathrm{m}$. (b) Area of lipid droplets. Values are means ( $n$ 5-6 mice per group), with their standard deviations represented by vertical bars. * Mean value was significantly different from that of the control $(C)$ group $(P<0.05$; Kruskal-Wallis test followed by Dunn's post hoc test). CA, control plus açaí; VC, vein; EXA, exercise plus açaí; EX, exercise.

of the açaí diet (1.6 (SD 0.3$) v .1 .0$ ( $\mathrm{SD} 0.2$ ) U/mg protein, respectively). There was a significant main effect of exercise on SOD activity, but no main effect of diet and no interaction were observed. There was no statistically significant different among the experimental groups with regard to CAT activity, as no significant main effects of exercise or diet and no interaction were observed.

\section{Expression of monocyte chemotactic protein-1 mRNA in the liver}

After 12 weeks of intervention, mice in the EX group exhibited a reduced mRNA expression of the inflammatory marker $M C P-1$ in the liver when compared with those in the $\mathrm{C}$ group (Fig. 3).

\section{Area of atherosclerotic lesions}

Figure 4(a) shows representative photomicrographs of the aortic lesion areas. There were no statistically significant differences $(P>0.05)$ among the groups when the values of the total area of aorta were compared (data not shown). Given that the aortas had similar areas, it was possible to compare the total area of lesions directly as a percentage of the total area of the aorta (total injured area/total area of the aorta $\times 100)$. En face analysis of the aortas revealed that mice in the EX group had a reduced percentage of lesion area when compared with those in the other groups (Fig. 4(b)). However, no differences were found among the C, CA and EXA groups.

\section{Serum lipid profile}

The serum levels of total cholesterol, TAG and HDLcholesterol were not affected in $A p o E^{-/-}$mice either by the ingestion of açaí pulp or by the aerobic exercise training programme (Table 4).

\section{Discussion}

In the present study, we investigated the effects of jussara açaí pulp consumption, either alone or in combination with moderate-intensity aerobic exercise training, on the hepatic oxidative and inflammatory status of $A p O E^{-1-}$ mice. We found that exercise training improved the hepatic oxidative status, reduced the mRNA expression of the inflammatory marker $M C P-1$ and decreased hepatic steatosis as well as atherosclerotic lesion area in $A p O E^{-/-}$mice. However, the ingestion of a diet containing $2 \%$ jussara açaí pulp alone did not affect these parameters. We also found that the combination of diet and exercise training (i.e. EXA group) improved the hepatic oxidative status of the mice by reducing SOD activity and attenuated

Table 3. Hepatocyte, sinusoidal capillary and inflammatory infiltrate measurements in the liver of $A p o E^{-/-}$mice fed a diet supplemented with açaí pulp and made to perform aerobic exercise (Mean values and standard deviations)

\begin{tabular}{|c|c|c|c|c|c|c|c|c|}
\hline \multirow[b]{3}{*}{ Measurements } & \multicolumn{8}{|c|}{ Experimental groups } \\
\hline & \multicolumn{2}{|c|}{$C(n 5)$} & \multicolumn{2}{|c|}{$\mathrm{CA}(n 6)$} & \multicolumn{2}{|c|}{$\operatorname{EXA}(n 6)$} & \multicolumn{2}{|c|}{$\operatorname{EX}(n 6)$} \\
\hline & Mean & SD & Mean & SD & Mean & SD & Mean & SD \\
\hline Hepatocyte (\%) & 74.46 & 5.05 & $66 \cdot 27$ & 5.75 & 72.02 & $2 \cdot 24$ & $67 \cdot 13$ & 4.56 \\
\hline Sinusoidal capillary (\%) & $7 \cdot 11$ & $2 \cdot 51$ & $6 \cdot 91$ & $1 \cdot 39$ & 9.95 & 0.72 & $12 \cdot 05^{\star} \dagger$ & 1.45 \\
\hline Inflammatory infiltrate (\%) & 0.26 & 0.30 & 0.51 & 0.55 & 0.25 & 0.22 & 0.31 & 0.25 \\
\hline
\end{tabular}

C, control; CA, control plus açaí; EXA, exercise plus açaí; EX, exercise.

${ }^{*}$ Mean value was significantly different from that of the $C$ group $(P<0.05$; Kruskal-Wallis test followed by Dunn's post hoc test).

† Mean value was significantly different from that of the CA group $(P<0.05$; Kruskal-Wallis test followed by Dunn's post hoc test). 


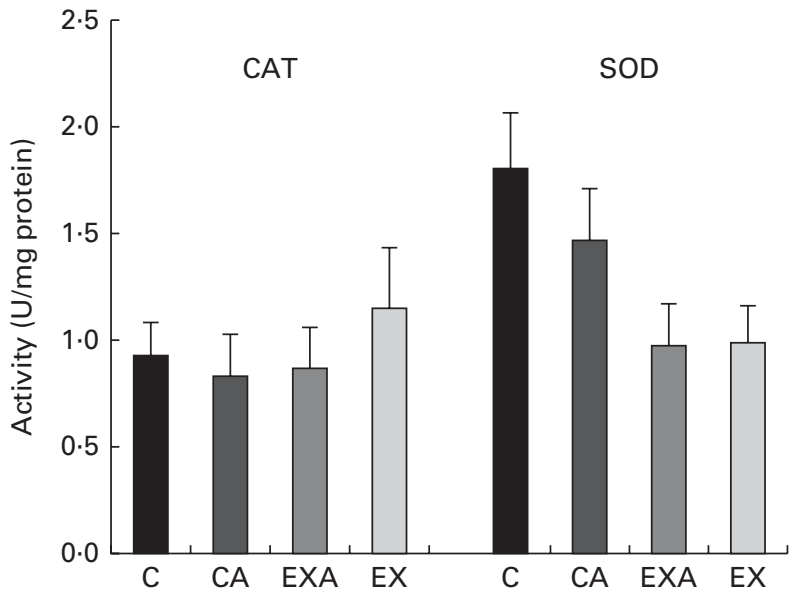

Fig. 2. Effects of açaí diet ingestion and aerobic exercise training on hepatic catalase (CAT) activity and hepatic superoxide dismutase (SOD) activity. The data were analysed using two-way ANOVA followed by Tukey's post hoc test. Values are means ( $n$ 5-6 mice per group), with their standard deviations represented by vertical bars. For CAT activity, there were no significant main effects for exercise $(P=0.06)$, diet $(P=0.57)$ and interaction $(P=0.12)$. There was a significant main effect of exercise $(P=0.01)$ for SOD activity, but no main effects for diet $(P=0.06)$ and interaction $(P=0.08)$. $C$, control; CA, control plus açaí; EXA, exercise plus açaí; EX, exercise.

hepatic steatosis, which indicates that alterations in these parameters are mainly due to exercise training.

To determine the effects of jussara açaí pulp consumption and exercise training on the hepatic antioxidant enzymes, CAT and SOD activities were determined. In the present study, $A p O E^{-1-}$ mice exhibited high levels of CAT and SOD activities in the liver, which could be the result of counteracting the excess of superoxide anions formed in these animals $^{(13)}$. CAT and SOD activities in the liver and skeletal muscle in response to aerobic exercise training have been found to increase, decrease or remain unchanged ${ }^{(16,18,34)}$. These discordant results obtained for the activity of antioxidant enzymes in response to exercise training could be explained by the different exercise conditions (i.e. intensity and duration) used and the enzymes analysed, as well as the organ and animal model used. In the present study, moderate-intensity aerobic exercise training alone was found to reduce SOD activity in $A p o E^{-/-}$mice (40.85\%), which suggests that the stress reduction induced by exercise diminishes the need for protective responses, although CAT activity was not altered. The exercise regimen used may have functioned to reduce the stressful environment present in this knockout mouse model. In this scenario, aerobic exercise training, a regular daily repetition of moderate-intensity exercise, contrary to exhaustive acute exercise, seems to decrease the production of ROS, which maintains the redox balance $^{(17)}$. For example, aerobic exercise training has been found to induce adaptive responses, including attenuation of increases in ROS production, lipid peroxidation levels and nuclear factor- $\kappa \mathrm{B}(\mathrm{NF}-\kappa \mathrm{B})$ activation and reduced glutathione:oxidised glutathione ratio in the liver of rats ${ }^{(15)}$. In addition, the skeletal muscle of mice subjected to endurance training has been reported to not release superoxide or NO and to exhibit no reductions in glutathione or protein thiol levels in response to in vitro isometric contractions. Furthermore, the contraction-induced activation of NF- $\mathrm{KB}$ and activator protein-1 DNA binding observed in the muscle of sedentary mice has not been observed in animals made to exercise ${ }^{(16)}$. These findings suggest that aerobic training decreases contraction-induced ROS generation, activation of redox-sensitive signalling pathways and ROS stress. Thus, although we did not measure these parameters, it is possible that the exercise regimen that we employed enhanced the ability of the liver to reduce ROS generation, which results in lower SOD activity.

The results obtained for SOD activity in the present study differ from those obtained in previous studies using a different açaí species, E. oleracea, and experimental conditions, as a diet supplemented with $2 \%$ of açaí pulp for 6 weeks was found to reduce SOD activity in the serum of a hypercholesterolaemic rat model ${ }^{(14)}$. In addition, SOD activity has been reported to be reduced in the brain of rats treated with açai ${ }^{(35)}$. However, an increased hepatic activity of antioxidant enzymes (i.e. glutathione reductase and glutathione peroxidase) has been reported in $A p o E^{-/-}$mice fed a diet with $5 \%$ of açaí pulp for 20 weeks $^{(13)}$. The results reported on the effects of polyphenols on CAT activity are also contradictory. For instance, unchanged ${ }^{(36)}$ or decreased activity ${ }^{(35)}$ has been demonstrated. These inconsistent results obtained for the activity of antioxidant enzymes could be explained by the different stress conditions used, the enzymes analysed, and the source of the dietary compounds.

To determine the effects of the applied treatments on the hepatic inflammatory condition, the mRNA expression of $M C P-1$ was analysed. The present results revealed a reduced ( $42 \%$ ) expression of $M C P-1 \mathrm{mRNA}$ in the liver of $A p O E^{-1-}$ mice in response to exercise training, but not as a result of açaí fruit pulp ingestion. Aerobic exercise training has been reported to decrease the levels of $\mathrm{MCP}-1$ in the plasma of individuals with the metabolic syndrome ${ }^{(37)}$ and normal individuals $^{(38)}$ and in the adipose tissue of obese mice ${ }^{(39)}$. It is worth noting that in association with ROS production in the liver of rats, aerobic exercise attenuates the hepatic activity of the redox-sensitive transcription factor NF- $\mathrm{BB}$, which is

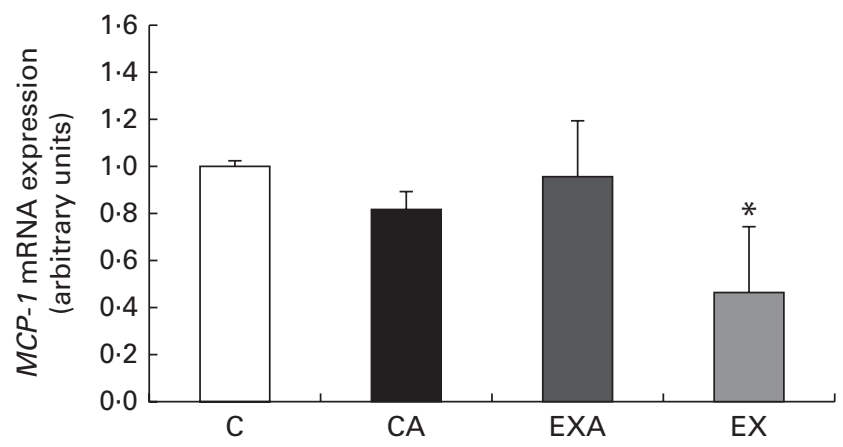

Fig. 3. Effects of açaí diet ingestion and aerobic exercise training on the mRNA expression of monocyte chemotactic protein-1 (MCP-1) in the liver of $A p o E^{-/-}$mice. Values are means ( $n 5-6$ mice per group), with their standard deviations represented by vertical bars. * Mean value was significantly different from that of the control (C) group $(P<0.05$; Kruskal-Wallis test followed by Dunn's post hoc test). CA, control plus açaí; EXA, exercise plus açaí; EX, exercise. 
(a)
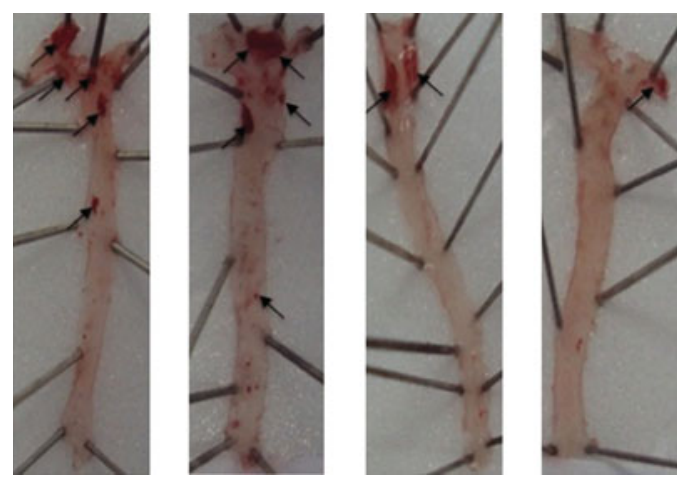

(b)

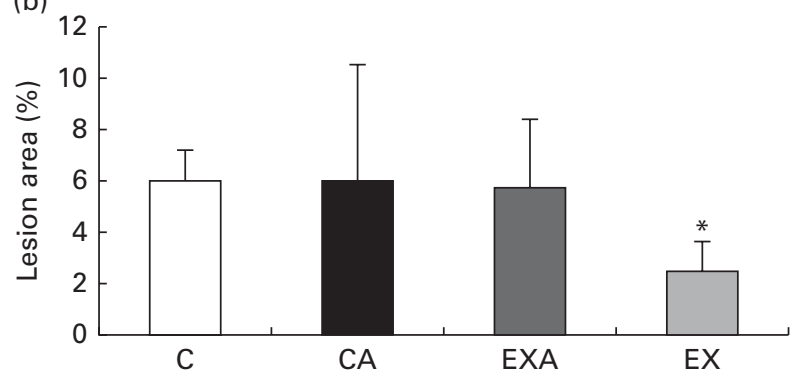

Fig. 4. Effects of açaí diet ingestion and aerobic exercise training on atherosclerotic lesion area in $A p o E^{-/-}$mice. (a) Representative photomicrographs of lesions areas in the descending aorta of $A p o E^{-/-}$mice in the experimental groups. Arrows indicate lesions. (b) Percentage of the lesion areas of mice in the experimental groups. Values are means ( $n 5-6$ mice per group), with their standard deviations represented by vertical bars. ${ }^{*}$ Mean value was significantly different from that of the control $(C)$ group $(P<0.05$; KruskalWallis test followed by Dunn's post hoc test). CA, control plus açaí; EXA, exercise plus açaí; EX, exercise. (A colour version of this figure can be found online at http://www.journals.cambridge.org/bjn)

involved in the regulation of various cellular processes such as the transcription of inflammation-related proteins ${ }^{(15,17)}$. Thus, the reduced hepatic oxidative status observed in the present study (i.e. decreased SOD activity) may help to explain the decreased expression of $M C P-1$ mRNA in the liver of $A p o E^{-/-}$mice that were made to exercise in the present study. In addition, MCP-1 is produced in, and secreted by, endothelial cells and its production is stimulated by mechanical stretch; thus, improved hepatic vascular function due to exercise might in part explain the inhibitory effect on chemokines $^{(40)}$. In fact, we observed that exercise training augmented the numbers of hepatic sinusoidal capillaries in $A p o E^{-/-}$ mice in the present study. In these animals, free radicals induce the release of vasoconstrictor enzymes from sinusoidal endothelial cells, which stimulate hepatic cells to contract, thus decreasing sinusoidal perfusion and leading to regional hypoxia $^{(41)}$. Unexpectedly, we did not find changes in the hepatic levels of $M C P-1$ mRNA in response to jussara açaî pulp ingestion either alone or in combination with aerobic exercise. Despite this, anthocyanins have been reported to exert anti-inflammatory effects by reducing the plasma levels of MCP-1 in human subjects ${ }^{(42)}$ and E. oleracea fruit pulp has been reported to reduce pro-inflammatory cytokine levels in $A p o E^{-/-}$mice $^{(13)}$.

In the present study, $A p o E^{-/-}$mice exhibited hepatic steatosis, as expected. Nevertheless, our data revealed that the percentage of hepatic lipid droplets in mice that were made to exercise was significantly reduced (70 and 56\%, respectively) when either treated or not treated with açaí, which indicates that such effects are mainly due to exercise training. Reduced hepatic steatosis in animals in response to regular exercise has been reported by others ${ }^{(43)}$. As a matter of fact, aerobic exercise is known to promote greater utilisation of fat by increasing its oxidation $^{(44)}$, which reduces its accumulation in the hepatocytes. It is worth noting that there is a strong relationship between the increased expression of $M C P-1$ in the liver and the condition of severe steatosis ${ }^{(45)}$. This relationship can be explained by the fact that MCP-1 induces lipid accumulation in hepatocytes through the activation of the gene expression of $P P A R \alpha^{(46)}$, which is involved in the regulation of intracellular lipids $^{(47)}$. Thus, the reduction of $M C P-1$ expression observed in mice that were made to exercise in the present study may help to explain the decreased deposition of hepatic lipid droplets in these animals.

On the other hand, the consumption of a diet containing $2 \%$ jussara açaí pulp alone did not change the lipid droplet formation in the liver of these mice. Different results in other models and diets have been reported previously. For example, the increased amounts of hepatic lipid droplets and area of epididymal adipocytes caused by the Western diet in LDL receptor-deficient mice have been reported to be reduced by naringenin, a flavonoid found in citrus fruits ${ }^{(48)}$. Moreover, the ingestion of melon juice extract, rich in SOD, has been found to attenuate the development of hepatic steatosis in hamsters fed an atherogenic diet ${ }^{(49)}$. Despite the differences among experimental models and designs, our findings

Table 4. Total cholesterol, TAG and HDL-cholesterol (HDL-C) levels in the serum of $A p o E^{-/-}$mice fed a diet supplemented with açaí pulp and made to perform aerobic exercise

(Mean values and standard deviations)

\begin{tabular}{|c|c|c|c|c|c|c|c|c|}
\hline \multirow[b]{3}{*}{ Measurements* } & \multicolumn{8}{|c|}{ Experimental groups } \\
\hline & \multicolumn{2}{|c|}{$C(n 5)$} & \multicolumn{2}{|c|}{$\mathrm{CA}(n 6)$} & \multicolumn{2}{|c|}{$\operatorname{EXA}(n 6)$} & \multicolumn{2}{|c|}{$\mathrm{EX}(n 6)$} \\
\hline & Mean & SD & Mean & SD & Mean & SD & Mean & SD \\
\hline Total cholesterol $(\mathrm{mmol} / \mathrm{l})$ & $11 \cdot 1$ & 0.8 & $11 \cdot 1$ & $1 \cdot 8$ & $9 \cdot 6$ & $2 \cdot 9$ & $10 \cdot 2$ & $2 \cdot 0$ \\
\hline TAG $(\mathrm{mmol} / \mathrm{l})$ & 0.7 & 0.2 & $1 \cdot 1$ & 0.4 & 0.6 & 0.3 & 0.7 & 0.3 \\
\hline $\mathrm{HDL}-\mathrm{C}(\mathrm{mmol} / \mathrm{l})$ & 0.6 & 0.1 & 0.8 & 0.2 & 0.7 & 0.2 & 0.7 & 0.3 \\
\hline
\end{tabular}

C, control; CA, control plus açaí; EXA, exercise plus açaí; EX, exercise.

* Data were analysed using the Kruskal-Wallis test. 
might also have been influenced by the high percentage of fat present in jussara açaí pulp (41\%).

In the present study, the serum lipid profile of $A p o E^{-/-}$ mice was not altered either by açaí pulp consumption or by aerobic exercise training or a combination of both. In line with these results, it has been reported that a diet containing anthocyanins (purple sweet potatoes, 1\%) does not affect the blood lipid profile in this animal model ${ }^{(50)}$. It is worth noting that in $A p o E^{-/-}$mice the plasma levels of cholesterol are approximately 5-fold higher than those in normal mice ${ }^{(51)}$; thus, the period of study employed by us might not have been sufficient to develop a significant change in the serum lipid profile. The results reported previously are not consensual inasmuch as there are studies showing that the serum lipid profile of $A p O E^{-/-}$mice is either changed ${ }^{(52)}$ or unchanged $^{(53)}$ in response to exercise training.

Despite having no effect on the serum lipid profile of the experimental groups in the present study, the exercise protocol alone reduced the area of aortic atherosclerotic lesions by $58 \%$, while the combination of jussara açaí pulp diet and aerobic exercise reduced the total area of atherosclerotic lesions (4\%). These findings are in agreement with those of previous studies in that aerobic exercise training promotes the regression of atherosclerotic lesions in $A p O E^{-/-}$mice and in other experimental models such as LDL receptordeficient mice ${ }^{(18)}$. The exercise-induced expression of $\mathrm{NO}$ synthase ${ }^{(54)}$ may contribute to the reduction of atherosclerotic lesion number as its inhibition accelerates atherosclerosis, although it was not assessed in the present study. Furthermore, exercise training has been reported to reduce atherosclerotic lesion number without changing blood lipid profile in $A p o E^{-/-}$mice $^{(52)}$. We observed that the levels of serum total cholesterol and TAG have little or no influence on fat deposition in the coronary arteries of patients with severe atherosclerosis, which may help to explain the reduction of atherosclerotic lesion number by factors other than decreased total cholesterol levels, including reduced inflammation, endothelial dysfunction and oxidative stress ${ }^{(55)}$. However, the consumption of a diet containing $2 \%$ jussara açaí pulp alone did not affect the area of atherosclerotic lesions in $A p o E^{-/-}$mice. In contrast to our findings, Xia et al. ${ }^{(56)}$ reported that an anthocyanin-rich extract from black rice reduced the size of advanced atherosclerotic lesions by $18 \%$ after 20 weeks of intervention in 30-week-old $A p o E^{-1-}$ mice. Such different findings between studies may be related not only to the age of the animals (21 v. 30 weeks) and lesion stage (stable plaque $v$. vulnerable plaque), but also to treatment duration (12 v. 20 weeks). Indeed, studies using 20-week interventions have obtained different results ${ }^{(13,56)}$

In conclusion, while the ingestion of a diet containing $2 \%$ jussara açaí pulp for 12 weeks did not affect the hepatic oxidative and inflammatory status of $A p o E^{-/-}$mice, moderateintensity aerobic exercise training improved the hepatic oxidative status, reduced the mRNA expression of the inflammatory marker $M C P-1$ and decreased hepatic steatosis as well as atherosclerotic lesion area in these animals. These findings do not support our hypothesis that the combination of a diet supplemented with açaí pulp and exercise training may potentiate the effects of jussara açaí pulp consumption on hepatic oxidative and inflammatory biomarkers.

\section{Acknowledgements}

M. C. G. P. and A. J. N. are CNPq fellows.

The present study was funded by the State of Minas Gerais Research Foundation (FAPEMIG). FAPEMIG had no role in the design and analysis of the study or in the writing of this article.

All authors contributed to the study design, outcome interpretation and manuscript preparation.

None of the authors has either financial or personal conflicts of interest to declare.

\section{References}

1. De Brito ES, de Araujo MC, Alves RE, et al. (2007) Anthocyanins present in selected tropical fruits: acerola, jambolao, jussara, and guajiru. J Agric Food Chem 55, 9389-9394.

2. Kong JM, Chia LS, Goh NK, et al. (2003) Analysis and biological activities of anthocyanins. Phytochemistry $\mathbf{6 4}$, 923-933.

3. Wallace TC (2011) Anthocyanins in cardiovascular disease. Adv Nutr 2, 1-7.

4. Mozaffarian D, Wilson PW \& Kannel WB (2008) Beyond established and novel risk factors: lifestyle risk factors for cardiovascular disease. Circulation 117, 3031-3038.

5. World Health Organization (2011) Global Atlas on Cardiovascular Disease Prevention and Control. Geneva: WHO.

6. Hansson G (2005) Inflammation, atherosclerosis, and coronary artery disease. $N$ Engl J Med 352, 1685-1695.

7. Targher G, Bertolini L, Padovani R, et al. (2006) Nonalcoholic fatty liver disease is associated with carotid artery wall thickness in diet-controlled type 2 diabetic patients. J Endocrinol Invest 29, 55-60.

8. Albano E (2006) Alcohol, oxidative stress and free radical damage. Proc Nutr Soc 65, 278-290.

9. Baggiolini M (1998) Chemokines and leukocyte traffic. Nature 392, 565-568.

10. Kanda H, Tateya S, Tamori Y, et al. (2006) MCP-1 contributes to macrophage infiltration into adipose tissue, insulin resistance, and hepatic steatosis in obesity. J Clin Invest 116, $1494-1505$

11. Smith SC, Allen J, Blair SN, et al. (2006) AHA/ACC guidelines for secondary prevention for patients with coronary and other atherosclerotic vascular disease: 2006 update: endorsed by the National Heart, Lung, and Blood Institute. Circulation 113, 2363-2372.

12. Jensen GS, Wu X, Patterson KM, et al. (2008) In vitro and in vivo antioxidant and anti-inflammatory capacities of an antioxidant-rich fruit and berry juice blend. Results of a pilot and randomized, double-blinded, placebo-controlled, crossover study. J Agric Food Chem 56, 8326-8333.

13. Xie C, Kang J, Burris R, et al. (2011) Açaí juice attenuates atherosclerosis in ApoE deficient mice through antioxidant and anti-inflammatory activities. Atherosclerosis 216, 327-333.

14. Souza MO, Silva M, Silva ME, et al. (2010) Diet supplementation with açaí (Euterpe oleracea Mart.) pulp improves biomarkers of oxidative stress and the serum lipid profile in rats. Nutrition 26, 804-810.

15. Radak Z, Chung HY, Naito H, et al. (2004) Age-associated increases in oxidative stress and nuclear transcription 
factor $\kappa \mathrm{B}$ activation are attenuated in rat liver by regular exercise. FASEB J 18, 749-750.

16. Brooks SV, Vasilaki A, Larkin LM, et al. (2008) Repeated bouts of aerobic exercise lead to reductions in skeletal muscle free radical generation and nuclear factor $\kappa \mathrm{B}$ activation. J Physiol 596, 3979-3990.

17. Radak Z, Chung HY \& Goto S (2008) Systemic adaptation to oxidative challenge induced by regular exercise. Free Rad Biol Med 44, 153-159.

18. Da Silva LA, Pinho CA, Rocha LGC, et al. (2009) Effect of different models of physical exercise on oxidative stress markers in mouse liver. Appl Physiol Nut Met 34, 60-65.

19. Teodoro BG, Natali AJ, Fernandes SAT, et al. (2012) Improvements of atherosclerosis and hepatic oxidative stress are independent of exercise intensity in $\mathrm{LDLr}^{-/-}$ mice. J Atheroscler Thromb 19, 904-911.

20. Association of Official Analytical Chemists (1989) Guidelines for collaborative study procedure to validate characteristics of a method of analysis. J Assoc Off Anal Chem 72, 694-704.

21. Giusti MM \& Wrosltad RE (2001) Anthocyanins. Characterization and measurement of anthocyanins by UV-visible spectroscopy. In Current Protocols in Food Analytical Chemistry Hand Book of Food Analytical Chemistry, pp. 1-13 [RE Wrolstad, editor]. New York, NY: John Wiley \& Sons.

22. Schauss AG, Wu X, Prior RL, et al. (2006) Phytochemical and nutrient composition of the freeze-dried Amazonian palm berry, Euterpe oleracea Mart. (açaî). J Agric Food Chem 54 , 8598-8603.

23. Reeves PG, Nielsen FH \& Fahey GC (1993) AIN-93 purified diets for laboratory rodents: final report of the American Institute of Nutrition ad hoc writing committee on the reformulation of the AIN-76A rodent diet. J Nutr 123, 1939-1951.

24. World Health Organization (2003) Fruit and vegetable promotion initiative report of the meeting, Geneva, 25-27 August 2003. Geneva: WHO

25. Souza MO, Silva LS, Magalhães CLB, et al. (2012) The hypocholesterolemic activity of açaí (Euterpe oleracea Mart.) is mediated by the enhanced expression of the ATP-binding cassette, subfamily $G$ transporters 5 and 8 and low-density lipoprotein receptor genes in the rat. Nutr Res 32, 976-984.

26. Høydal MA, Wisløff U, Kemi OJ, et al. (2007) Running speed and maximal oxygen uptake in rats and mice: practical implications for exercise training. Eur J Cardiovas Prev Rehab 14, 753-760.

27. Alp PR, Newsholme EA \& Zammit VA (1976) Activities of citrate synthase and $\mathrm{NAD}^{+}$-linked and $\mathrm{NADP}^{+}$-linked isocitrate dehydrogenase in muscle from vertebrates and invertebrates. Biochem J 154, 689-700.

28. Dieterich S, Bieligk U, Beulich K, et al. (2000) Gene expression of antioxidative enzymes in the human heart: increased expression of catalase in the end-stage failing heart. Circulation 101, 33-39.

29. Lowry OH, Rosebrough NJ, Farr AL, et al. (1951) Protein measurement with Folin phenol reagent. J Biol Chem 193, $265-275$.

30. Aebi H (1984) Catalase in vitro. Methods Enzimol 105, 121-127.

31. Pfall MW (2001) A new mathematical model for relative quantification in real-time PCR. Nucleic Acids Res 29, 45-53.

32. Livak KJ \& Schmittgen TD (2001) Analysis of relative gene expression data using real-time quantitative PCR and the 2 ( $-\Delta \Delta \mathrm{CT})$ method. Methods 25, 402-408.

33. Palinski W, Ord VA, Plump AS, et al. (1994) ApoE-deficient mice are a model of lipoprotein oxidation in atherogenesis. Demonstration of oxidation-specific epitopes in lesions and high titers of autoantibodies to malondialdehyde-lysine in serum. Arterioscler Thromb 14, 605-616.

34. Alessio HM \& Goldfarb AH (1988) Lipid peroxidation and scavenger enzymes during exercise: adaptative response to training. J Appl Physiol 64, 1333-1336.

35. Spada PDS, Dani C, Bortolini GV, et al. (2009) Frozen fruit pulp of Euterpe oleracea Mart. (açai) prevents hydrogen peroxide-induced damage in the cerebral cortex, cerebellum, and hippocampus of rats. J Med Food 12, 1084-1088.

36. Dragsted LO, Pedersen A, Hermetter A, et al. (2004) The 6-a-day study: effects of fruit and vegetables on markers of oxidative stress and antioxidative defense in healthy nonsmokers. Am J Clin Nutr 79, 1060-1072.

37. Trøseid M, Lappegard KT, Claudi T, et al. (2004) Exercise reduces plasma levels of the chemokines MCP-1 and IL-8 in subjects with the metabolic syndrome. Eur Heart $J \mathbf{2 5}$, 349-355.

38. Garelnabi M, Veledar E, White-Welkley J, et al. (2012) Vitamin E differentially affects short term exercise induced changes in oxidative stress, lipids, and inflammatory markers. Nutr Metab Cardiovasc 22, 907-913.

39. Vieira VJ, Valentine RJ, Wilund KR, et al. (2009) Effects of exercise and low-fat diet on adipose tissue inflammation and metabolic complications in obese mice. Am J Physiol Endocrinol Metab 296, E1164-E1171.

40. Maiorana A, O'Driscoll G, Cheetham C, et al. (2001) The effect of combined aerobic and resistance exercise training on vascular function in type 2 diabetes. $\mathrm{J} \mathrm{Am} \mathrm{Coll} \mathrm{Cardiol}$ 38, 860-866.

41. Daugherty A (2002) Mouse models of atherosclerosis. Am J Med Sci 323, 3-10.

42. Garcia-Alonso M, Minihane AM, Rimbach G, et al. (2009) Red wine anthocyanins are rapidly absorbed in humans and affect monocyte chemoattractant protein 1 levels and antioxidant capacity of plasma. J Nutr Biochem 20, 521-529.

43. Rector RS, Thyfault JP, Morris RT, et al. (2008) Daily exercise increases hepatic fatty acid oxidation and prevents steatosis in Otsuka Long-Evans Tokushima Fatty rats. Am J Physiol Gastrointest Liver Physiol 294, G619-G626.

44. Helge JW (2002) Long-term fat diet adaptation effects on performance, training capacity, and fat utilization. Med Sci Sports Exerc 34, 1499-1504.

45. Rull A, Rodriguez F, Aragones G, et al. (2009) Hepatic monocyte chemoattractant protein-1 is upregulated by dietary cholesterol and contributes to liver steatosis. Cytokine $\mathbf{4 8}$, 273-279.

46. Gao B (2005) Cytokines, STATs and liver disease. Cell Mol Immunol 2, 92-100.

47. Qin X, Xie X, Fan Y, et al. (2008) Peroxisome proliferatoractivated receptor-delta induces insulin-induced gene-1 and suppresses hepatic lipogenesis in obese diabetic mice. Hepatology 48, 432-441.

48. Mulvihill E, Assini JM, Sutherland BG, et al. (2010) Naringenin decreases progression of atherosclerosis by improving dyslipidemia in high-fat-fed low-density lipoprotein receptor-null mice. Arterioscler Thromb Vasc Biol 30, 742-748.

49. Decorde K, Ventura E, Lacan D, et al. (2010) An SOD rich melon extract Extramel prevents aortic lipids and liver steatosis in diet-induced model of atherosclerosis. Nutr Metab Cardiovasc Dis 20, 301-307.

50. Miyazaki K, Makino K, Iwadate E, et al. (2008) Anthocyanins from purple sweet potato Ipomoea batatas cultivar Ayamurasaki suppress the development of atherosclerotic lesions and both enhancements of oxidative stress and soluble vascular cell adhesion molecule-1 in apolipoprotein E-deficient mice. J Agric Food Chem 56, 11485-11492. 
51. Piedrahita JA, Zhang SH, Hagaman JR, et al. (1992) Generation of mice carrying a mutant apolipoprotein $\mathrm{E}$ gene inactivated by gene targeting in embryonic stem cells. Proc Natl Acad Sci U S A 89, 4471-4475.

52. Shimada K, Mikami Y, Murayama T, et al. (2011) Atherosclerotic plaques induced by marble-burying behavior are stabilized by exercise training in experimental atherosclerosis. Int J Cardiol 151, 284-289.

53. Meilhac O, Ramachandran S, Chiang K, et al. (2001) Role of arterial wall antioxidant defense in beneficial effects of exercise on atherosclerosis in mice. Arterioscler Thromb Vasc Biol 21, 1681-1688.
54. Fukai T, Siegfried MR, Ushio-Fukai M, et al. (2000) Regulation of the vascular extracellular superoxide dismutase by nitric oxide and exercise training. J Clin Invest 105, 1631-1639.

55. Braz DJ Jr, Gutierrez PS \& Da Luz PL (2007) Coronary fat content evaluated by morphometry in patients with severe atherosclerosis has no relation with serum lipid levels. Braz J Med Biol Res 40, 467-473.

56. Xia M, Ling W, Zhu H, et al. (2009) Anthocyanin attenuates CD40-mediated endothelial cell activation and apoptosis by inhibiting CD40-induced MAPK activation. Atherosclerosis 202, $41-47$. 